\title{
Effect of dietary methionine on plasma and liver cholesterol concentrations in rats and expression of hepatic genes involved in cholesterol metabolism
}

\author{
F. Hirche, A. Schröder, B. Knoth, G. I. Stangl and K. Eder* \\ Institute of Nutritional Sciences, Martin-Luther-University of Halle-Wittenberg, 06108 Halle, Germany \\ (Received 3 August 2005 - Revised 8 December 2005 - Accepted 16 December 2005)
}

\begin{abstract}
Methionine has been shown to increase plasma cholesterol in animals. In the present study, mechanisms were investigated by which methionine could alter cholesterol metabolism. In the first experiment, forty growing rats were fed four casein-based diets differing in methionine content $(2 \cdot 6,3 \cdot 5,4.5$ or $6.0 \mathrm{~g} / \mathrm{kg})$ for $14 \mathrm{~d}$. In the second experiment, isolated rat hepatocytes were incubated in media supplemented with 50,100 or $200 \mu \mathrm{mol} / 1 \mathrm{methionine.} \mathrm{Dietary} \mathrm{methionine} \mathrm{tended} \mathrm{to} \mathrm{increase} \mathrm{plasma} \mathrm{homocysteine} \mathrm{concentrations} \mathrm{in} \mathrm{the} \mathrm{rats}(P=0 \cdot 058)$. A weak positive correlation between circulating homocysteine and plasma cholesterol was observed $\left(R^{2} 0 \cdot 27, P<0.01\right)$. Rats fed $3.5 \mathrm{~g} / \mathrm{kg}$ or more of methionine had higher concentrations of cholesterol in their plasma, in lipoprotein fractions of density $(\rho ; \mathrm{kg} / \mathrm{l}) 1.006<\rho<1.063$ and $\rho>1.063$, and in liver than rats fed $2.6 \mathrm{~g} / \mathrm{kg}$ methionine. Rats fed $6 \mathrm{~g} / \mathrm{kg}$ methionine had a higher hepatic expression of 3-hydroxy-3-methylglutaryl coenzyme A reductase and cholesterol-7 $\alpha$-hydroxylase than rats fed less methionine. The phosphatidylcholine:phosphatidylethanolamine ratio in rat liver increased with rising dietary methionine concentration; the relative mRNA concentrations of phosphatidylethanolamine N-methyltransferase and cystathionine $\beta$-synthase remained unaffected. Hepatocytes incubated in media supplemented with 100 or $200 \mu \mathrm{mol} / \mathrm{l}$ methionine had a higher cholesterol synthesis than hepatocytes incubated in a medium supplemented with $50 \mu \mathrm{mol} / \mathrm{l}$ methionine; the LDL uptake in hepatocytes was independent of the methionine concentration of the medium. In conclusion, the present study suggests that dietary methionine induces hypercholesterolaemia at least in part via an enhanced hepatic cholesterol synthesis.
\end{abstract}

Methionine: Homocysteine: Cholesterol metabolism: Liver: Rat

Previous studies on the effects of dietary proteins on plasma cholesterol have shown that casein raises serum and LDL-cholesterol concentration in animals and man, whereas plant proteins such as soya protein do not (Ikeda et al. 1993; Kritchevsky, 1993; Sirtori et al. 1993; Sugano \& Koba, 1993; Carroll \& Kurowska, 1995). The results obtained from these studies suggest that alterations in plasma cholesterol concentration could be mediated by differences in the amino acid patterns of the dietary proteins. Methionine is one of the amino acids that could contribute to this phenomenon because it is more abundant in casein than in soya protein. Sugiyama et al. (1998) have shown that high concentrations of dietary methionine increase plasma phosphatidylcholine, the phosphatidylcholine:phosphatidylethanolamine ratio of liver microsomes and the cholesterol concentration in rat plasma. In support of this finding, Giroux et al. (1999) reported that concentrations of hepatic phosphatidylcholine and plasma cholesterol were higher in rabbits fed a diet enriched with L-lysine and L-methionine.

Both research groups proposed that hypercholesterolaemia induced by high dietary methionine concentrations might be caused by alterations in hepatic phospholipid metabolism.
Dietary methionine is mainly metabolised in the liver, where it is converted to S-adenosylmethionine (SAM). SAM functions as methyl donor for the methylation of phosphatidylethanolamine into phosphatidylcholine. It is suggested that methionine could influence the formation of phosphatidylcholine by increasing the availability of methyl groups from SAM via a phosphatidylethanolamine $N$-methyltransferase (PEMT)-mediated pathway. Phosphatidylcholine is the major phospholipid class of plasma lipoproteins and is required for the assembly and secretion of apo-B-containing lipoproteins from liver into the plasma (Yao \& Vance, 1988). On the other hand, the phosphatidylcholine:phosphatidylethanolamine ratio in the liver seems to have a regulatory function in cholesterol metabolism because previous findings have demonstrated that methionine-induced hypercholesterolaemia is completely abolished by supplementation with eritadenine, a potent inhibitor of phosphatidylethanolamine $N$-methylation (Sugiyama et al. 1998). Additionally, it is known that canalicular membrane phosphatidylcholine synthesis in liver, in concert with the phospholipid transporter, promotes the excretion of phospholipid and cholesterol into the bile (Sehayek et al. 2003), a mechanism that normally contributes to a reduction in cholesterol concentration in the plasma. 
By donating its labile methyl group, SAM becomes S-adenosylhomocysteine (SAH), which can be remethylated to SAM or converted into cysteine, a reaction that depends on the action of cystathionine $\beta$-synthase. SAH can be converted to homocysteine. Recent findings indicate that homocysteine has a hypercholesterolaemic action by stimulating cholesterol biosynthesis via activation of the transcription factors sterol regulatory element-binding protein-2, cAMP response element-binding protein and nuclear factor $\mathrm{Y}$ in the liver (Woo et al. 2005). It is also possible therefore that the hypercholesterolaemic action of methionine is caused by the homocysteine-induced stimulation of cholesterol biosynthesis. The expression of the LDL receptor gene, another sterol regulatory element-binding protein-2-dependent gene, has not yet been investigated in this respect. However, the molecular basis of the effect of methionine on the cholesterol metabolism is not yet fully understood.

The present study was therefore undertaken to find out more about the effects of dietary methionine on cholesterol metabolism. Growing rats were used as the model. To explore possible dose-dependent effects of dietary methionine, we used four diets with methionine concentrations of 2.6, 3.5, 4.5 and $6.0 \mathrm{~g} / \mathrm{kg}$. The diet with the methionine concentration of $4.5 \mathrm{~g} / \mathrm{kg}$ matched the recommended intake for growing rats (AIN-93G; Reeves et al. 1993). Diets with $2.6 \mathrm{~g} / \mathrm{kg}$ and $3.5 \mathrm{~g} / \mathrm{kg}$ methionine represented low-methionine diets. The diet containing $6.0 \mathrm{~g} / \mathrm{kg}$ methionine was representative of a moderate methionine excess. All the diets met the minimum requirement for methionine and sulphur-containing amino acids to prevent growth retardation in growing rats. A possible effect of dietary methionine on cholesterol excretion was investigated by determining the gene expression for cholesterol-7 $\alpha$-hydroxylase (CYP7A1) in the liver, the key enzyme in the synthesis of bile acids from cholesterol, and by measuring bile acids in the faeces. We also tested whether dietary methionine could alter the synthesis of phosphatidylcholine and phosphatidylethanolamine and the expression of PEMT, one of the main enzymes involved in phosphatidylcholine synthesis. We suggested that an alteration of the phosphatidylcholine:phosphatidylethanolamine ratio might alter membrane fluidity and, as a consequence, fatty acid desaturation. We therefore determined the gene expression of $\Delta 6$-desaturase in liver and the ratio of arachidonic to linoleic acid, an indicator of $\Delta 6$ - desaturase activity in liver phospholipids.

Cholesterol biosynthesis in the liver and the uptake of LDL from the plasma into the cells via the LDL receptor are other important processes involved in the regulation of plasma cholesterol concentration. A determination of the relative mRNA concentration in the liver of 3-hydroxy-3-methylglutaryl coenzyme A (HMG-CoA) reductase, the key enzyme in cholesterol biosynthesis, and the relative mRNA concentration of the LDL receptor in rat liver should provide further information about the effects of methionine on cholesterol metabolism in vivo. To ascertain the possible effects of methionine on the uptake of LDL by the LDL receptor and on cholesterol biosynthesis, we additionally performed a study with primary rat hepatocytes cultivated in media with different concentrations of methionine. Primary rat hepatocytes were used as in vitro model to obtain further data about possible mechanisms by which methionine could alter cholesterol concentrations in rats. The concentrations of homocysteine in the plasma and liver of rats in response to diets with a different methionine concentration were measured in order to elucidate a potential link between dietary methionine, plasma homocysteine and plasma cholesterol.

\section{Materials and methods}

\section{Feeding experiment}

Forty 4-week-old male Sprague-Dawley rats were obtained from Charles River (Sulzfeld, Germany). They were housed individually in Macrolon cages in a temperature- $\left(23 \pm 1^{\circ} \mathrm{C}\right)$ and humidity-controlled $(50-60 \%)$ room with a $12 \mathrm{~h}$ light/ dark cycle ( 10.00 hours to 22.00 hours). The rats were acclimatised to the facility for $7 \mathrm{~d}$ and given free access to a stock diet (Altromin, Lage, Germany). At 5 weeks of age, the rats were randomly assigned to one of four groups of ten rats each with similar initial mean body weights (group 1, 123 (SEM 2.2) g; group 2, 122 (SEM 2.9) g; group 3, 122 (SEM 3.3) g; group 4, 123 (SEM 3.1) g). The experiment followed established guidelines for the care and handling of laboratory animals approved by the council of SaxonyAnhalt.

A basal semisynthetic diet was used. The composition of the experimental diets is shown in Table 1. Diets were prepared by mixing the dry components with fat and water, followed by freeze-drying. The residual water content of the diets was below $5 \mathrm{~g}$ per $100 \mathrm{~g}$ diet. The composition of the vitamin and mineral mixture followed recommendations from the National Research Council (1995). Casein was obtained from Meggle (Wasserburg, Germany), L-methionine from Sigma-Aldrich (Deisenhofen, Germany) and the other amino acids from Lohmann Animal Health (Cuxhaven, Germany). The amount of total sulphur amino acids (methionine and cysteine) in the diets was maintained at a constant level on a molar basis, equivalent to an amount of methionine of $8 \mathrm{~g} / \mathrm{kg}$ diet. No supplemental methionine was added to the diet containing $2.6 \mathrm{~g} / \mathrm{kg}$ methionine. The other diets were

Table 1. Composition of experimental diets differing in methionine

\begin{tabular}{lcccc}
\hline & \multicolumn{4}{c}{ Experimental diets } \\
\cline { 2 - 5 } & \multicolumn{3}{c}{ Dietary methionine concentration $(\mathrm{g} / \mathrm{kg})$} \\
\cline { 2 - 5 } Ingredient & $2 \cdot 6$ & $3 \cdot 5$ & 4.5 & $6 \cdot 0$ \\
\hline Casein & 100 & 100 & 100 & 100 \\
Free amino acid mixture* & $87 \cdot 1$ & $87 \cdot 1$ & $87 \cdot 1$ & $87 \cdot 1$ \\
Maize starch & $490 \cdot 8$ & $490 \cdot 7$ & $490 \cdot 5$ & $490 \cdot 2$ \\
Sucrose & 215 & 215 & 215 & 215 \\
Maize oil & 50 & 50 & 50 & 50 \\
Cellulose & 20 & 20 & 20 & 20 \\
Vitamin and mineral mixture† & 29 & 29 & 29 & 29 \\
Choline chloride & 4 & 4 & 4 & 4 \\
L-methionine & 0 & 0.9 & 1.9 & 3.4 \\
Cysteine & $4 \cdot 1$ & 3.3 & 2.5 & 1.3 \\
\end{tabular}

*The following amino acids were supplemented ( $\mathrm{g} / \mathrm{kg}$ diet): lysine ${ }^{\star} \mathrm{HCl}, 8.27$; threonine, 3.38; arginine ${ }^{*} \mathrm{HCl}, 4.37$; histidine, 2.51; isoleucine, 4.51; leucine, 7.75; phenylalanine, 4.25 ; valine, 5.51 ; aspartic acid, 5.75 ; glutamic acid, 17.5 ; glycine, 1.49; proline, 9.38; serine, 4.25; tyrosine, 4.63; alanine, 2.51; tryptophan, 1.05.

†The vitamin and mineral mixture was composed according to recommendations from the National Research Council (1995).

For details of diets and procedures, see this page. 
supplemented with L-methionine to bring the total methionine content to $3.5,4.5$ and $6.0 \mathrm{~g} / \mathrm{kg}$ (Table 1 ).

All the diets were supplemented with cysteine to contain $4.5,3.7,2.9$ and $1.7 \mathrm{~g} / \mathrm{kg}$ cysteine (Table 1). The other amino acids were added in the form of a free amino acid mixture and did not differ between the four experimental diets (Table 1). The total dietary concentrations of the other amino acids were ( $\mathrm{g} / \mathrm{kg}$ diet): lysine, $13 \cdot 3$; threonine, $7 \cdot 3$; arginine, 6.8; histidine, 5.7; isoleucine, 8.9 ; leucine, $16 \cdot 6$; phenylalanine, 9.1; valine, 11.5; aspartic acid, 12.4; glutamic acid, 38.6; glycine, 3.2 ; proline, 19.5 ; serine, $9 \cdot 6$; tyrosine, 9.0 ; alanine, $5 \cdot 3$. The concentration of tryptophan was not determined for technical reasons. Based on literature values for casein and the amount supplemented, the tryptophan concentration was estimated to be $2 \cdot 2 \mathrm{~g} / \mathrm{kg}$.

The rats were fed once daily at 09.00 hours. Diets were supplied ad libitum. The daily feed intake was recorded by weighing the amount of diet not eaten by the rats. Water was available from nipple drinkers.

\section{Sample collection and preparation}

After a feeding period of $14 \mathrm{~d}$, the non-fasted rats were killed by decapitation under light anaesthesia with diethyl ether (09.00 hours to 11.00 hours). Rats were not fasted before killing because food deprivation leads to a significant downregulation of the genes encoding enzymes involved in lipid metabolism (Shimano et al. 1999), which were to be measured in the present study. Plasma was separated from heparinised whole blood by centrifugation at $1880 \mathrm{~g}$ for $10 \mathrm{~min}$ at $4^{\circ} \mathrm{C}$. Plasma lipoproteins were separated by step-wise ultracentrifugation (Mikro-Ultrazentrifuge; Sorvall Products, Bad Homburg, Germany) at $900000 \mathrm{~g}$ at $4^{\circ} \mathrm{C}$ for $1.5 \mathrm{~h}$. The lipoprotein fractions were collected on the basis of their densities $(\rho ; \mathrm{kg} / \mathrm{l})$ as described previously for rats (Giudetti et al. 2003): $\rho<1.006 \mathrm{~kg} / \mathrm{l}, 1.006 \mathrm{~kg} / \mathrm{l}<\rho<1.063 \mathrm{~kg} / \mathrm{l}$ and $\rho>1.063 \mathrm{~kg} / \mathrm{l}$. Plasma densities were adjusted with $\mathrm{NaCl}$ and $\mathrm{KBr}$. The lipoprotein fractions used for cholesterol analysis were removed by suction. Livers were excised, weighed and immediately snap-frozen in liquid N. Aliquots of liver for RNA isolation were stored at $-80^{\circ} \mathrm{C}$; other samples were stored at $-20^{\circ} \mathrm{C}$. During the second week of the experimental period, faeces were collected, dried, weighed and stored at $-20^{\circ} \mathrm{C}$ until analysis.

\section{Lipid analyses}

Lipids from liver and cultivated cells were extracted with a mixture of $\mathrm{n}$-hexane and isopropanol $(3: 2, \mathrm{v} / \mathrm{v}$; Hara \& Radin, 1978). The concentrations of lipids in liver were determined using an enzymatic reagent kit after drying an aliquot of the lipid extracts and dissolving the lipids with Triton X-100 (De Hoff et al. 1978). Concentrations of cholesterol in the liver, plasma and lipoprotein fractions were determined using an enzymatic reagent kit (Cat.-No. 1.14830; VWR International, Darmstadt, Germany).

The phosphatidylcholine and phosphatidylethanolamine fractions of the extracts were separated by normal-phase HPLC equipped with a fraction collector using a Kromasil column $(12.5 \mathrm{~cm} \times 0.46 \mathrm{~cm}$, Si $5 \mu \mathrm{m}, 100 \mathrm{~nm}$; Chromatographie Service, Langerwehe, Germany) and an elution system consisting of $n$-hexane-isopropanol $(80: 20, \mathrm{v} / \mathrm{v})$ and methanol (Christie, 1985). After evaporation of the elution solvents using a centrifugal evaporator, phosphatidylcholine and phosphatidylethanolamine were methylated with trimethylsulphonium hydroxide (Butte, 1983). Fatty acid methyl esters were separated by GC (Eder \& Brandsch, 2002). The ratio of arachidonic acid (20: $4 n-6)$ to linoleic acid (18: $2 n-6)$ was calculated on a molar basis. The concentrations of phosphatidylcholine and phosphatidylethanolamine in the lipid extracts were determined by quantitative high-performance thin-layer chromatography on HPTLC plates Si60 (Cat.-No. 1.05 633; VWR International). Samples and standards were applied with a Linomat 5 , and the chromatography plates were developed in a horizontal chamber (both from Camag, Muttenz, Switzerland) with a mixture of chloroform-methanol-concentrated ammonia (26:10:1·6, v/v/v). Lipids were visualised by dipping in $10 \%$ aqueous ammonium sulphate and stained at $200^{\circ} \mathrm{C}$. Spots were evaluated densitometrically using video equipment and the corresponding software from Syngene (Cambridge, UK). The ratio of phosphatidylcholine:phosphatidylethanolamine was calculated on a molar basis.

The content of total bile acids in the faeces was determined enzymatically (DiaSys Diagnostic Systems, Holzheim, Germany) by a modified method of Marlett \& Fischer (2002) using taurocholic acid as a standard. For that purpose, the bile acids were extracted from freeze-dried faeces with ethanol and $\mathrm{NaOH}$ as recently described (Dongowski et al. 2002).

Analyses of amino acids, homocysteine, S-adenosylmethionine and S-adenosylhomocysteine

The amino acid concentrations of the diets were determined with an amino acid analyser (LC3000; Eppendorf, Hamburg, Germany) after the diets had been digested with $\mathrm{HCl}$ (Bassler \& Buchholz, 1993). The concentrations of free amino acids in the plasma and in cell culture media were measured as isoindole derivatives by HPLC (1100 series; Agilent Technologies, Waldbronn, Germany) according to Schuster (1988) after pre-column derivatisation (Teerlink et al. 1994). Amino acid isoindoles were detected at an excitation wavelength of $337 \mathrm{~nm}$ and an emission wavelength of $454 \mathrm{~nm}$.

Total homocysteine and total cysteine were also determined by HPLC (Vester \& Rasmussen, 1991). To measure the hepatic homocysteine concentrations, aliquots of liver were thawed and homogenised in ice-cold PBS; the homocysteine concentrations were determined by HPLC according to the method of Vester \& Rasmussen (1991). The concentrations of SAM and SAH in the liver were measured by HPLC according to Sugiyama et al. (1995). Samples of frozen liver were thawed and homogenised in $0.5 \mathrm{~mol} / 1$ icecold perchloric acid, and the homogenates were centrifuged at $16000 \mathrm{~g}$ for $20 \mathrm{~min}$ at $4^{\circ} \mathrm{C}$. The resultant supernatants were applied to a HPLC column (Hypersil ODS $250 \times 4 \mathrm{~mm}^{2}, 5 \mu \mathrm{m} ;$ Agilent Technologies). The mobile phase was a $100 \mathrm{mmol} / \mathrm{l}$ potassium dihydrogen phosphate solution containing $10 \mathrm{mmol} / \mathrm{l}$ sodium heptane sulphonate and $3 \%(\mathrm{v} / \mathrm{v})$ methanol. The flow rate was $1.5 \mathrm{ml} / \mathrm{min}$, and the elution was monitored at $254 \mathrm{~nm}$. 


\section{Gene expression analyses}

For analysis of gene expression, total RNA was extracted from frozen liver samples using Trizol reagent (Invitrogen, Karlsruhe, Germany). RNA was quantified by $\mathrm{A}_{260}$ and its integrity verified by agarose gel electrophoresis using ethidium bromide for visualisation. Total RNA and oligo dT primer (Amersham Pharmacia, Freiburg, Germany) were used for cDNA synthesis (Omniscript RT Kit from Qiagen, Hilden, Germany; Mastercycler Personal from Eppendorf). The concentration of cDNA was analysed by real-time detection PCR using Sybr green I (Rotorgene 2000; Corbett Research, Mortlake, Australia). The amplification efficiency and the take-off point calculated by Rotorgene software 4.6 were used for comparative quantification. Different runs were made comparable by purified PCR products, with the extraction of cut ethidium bromide-stained bands following $2 \%$ agarose gel electrophoresis by MiniElute Gel Extraction Kit (Qiagen) used as a standard. The expression signal of the housekeeping gene glyceraldehyde-3-phosphate dehydrogenase served as internal control for normalisation. PCR was carried out using $100 \mu \mathrm{l}$ Rotorgene PCR tubes with a final volume of $15 \mu \mathrm{l}$ reaction mixture containing $500 \mu \mathrm{mol} / \mathrm{l}$ dNTP (Roth, Karlsruhe, Germany), $3.5 \mathrm{mmol} / 1 \mathrm{MgCl}_{2}, 5 \mathrm{U}$ Taq DNA polymerase and $1.5 \mu \mathrm{l} 10 \times$ buffer (all from Promega, Mannheim, Germany), $0.38 \mu \mathrm{l} 10 \mathrm{x}$ Sybr Green I (Sigma-Aldrich), $2 \mu$ l first-strand cDNA or standard, and $2 \mu \mathrm{l}$ primer mix. The primer oligonucleotides were selected using Primerselect software (DNA-Star Inc., Madison, WI, USA) and Abi-Prism Primerpairs software (Applied Biosystems, Weiterstadt, Germany) from database sequences (Roth).

The sequences, product length and concentrations in the stock solutions were:

1. glyceraldehyde-3-phosphate dehydrogenase (EC 1.2.1.12; EMBL ID: RNAGAPDHR), up: 5'-GCA TGG CCT TCC GTG TTC C-3', low: $5^{\prime}$-GGG TGG TCC AGG GTT TCT TAC TC-3'; $337 \mathrm{bp}, 1.5 \mathrm{pmol} / \mu \mathrm{l}$;

2. PEMT (EC 2.1.1.17; NCBI GenBank: NM013003), up: 5'-GCC CAG CTC CCA TTT CCT TC-3', low: 5'-CAT CTT GGG CTG GCT CAT CAT-3'; 286 bp, $10 \mathrm{pmol} / \mu \mathrm{l}$;

3. CYP7A1 (EC 1·14.13.17; NCBI GenBank: J05509), up: 5'-CAA GAC GCA CCT CGC TAT CC -3', low: 5'-CCG GCA GGT CAT TCA GTT G-3'; $206 \mathrm{bp}, 10 \mathrm{pmol} / \mu \mathrm{l}$;

4. cystathionine $\beta$-synthase (EC $4 \cdot 2 \cdot 1 \cdot 22$; NCBI GenBank: NM 012522), up: 5'-CAG TGC GAC GGG AAG GTG GAC A - $3^{\prime}$, low: 5'-ATG CGG GCG AAG GCG AAG GA -3'; $284 \mathrm{bp}, 5 \mathrm{pmol} / \mu \mathrm{l}$;

5. HMG-CoA reductase (EC 1.1.1.34), up: 5'-CAG GGA ACA TGC ACC AAG AAG G-3', low: 5'-ATA CGG CAC GGA AAG AAC CAT AGT-3'; 237 bp, 10 pmol/ $\mu \mathrm{l}$;

6. LDL receptor (NCBI GenBank: X13722), up: 5'-AGT GGC CGC CTC TAT TGG GTT GAT-3', low: 5'-TCC GGG GAC ATG AGG TTT TTA GC-3'; 236 bp, 2.5 pmol/ $\mu 1$;

7. $\Delta 6$-desaturase (EC 1.14.99; EMBL ID: AB621980), up: 5'-CTT TCT CCT CCT GTC CCA CAT-3', low: 5'-CAT TGC CGA AGT ACG AGA GGA-3'; 71 bp, 7.5 pmol/ $\mu 1$.

The DNA of glyceraldehyde-3-phosphate dehydrogenase, PEMT, CYP7A1, cystathionine $\beta$-synthase, HMG-CoA reductase, $\mathrm{LDL}$ receptor and $\Delta 6$-desaturase was amplified in cycles of $20 \mathrm{~s}$ denaturation at $95^{\circ} \mathrm{C}, 30 \mathrm{~s}$ annealing at $60^{\circ} \mathrm{C}$ and $40 \mathrm{~s}$ elongation at $72^{\circ} \mathrm{C}$. Fluorescence was measured at $72^{\circ} \mathrm{C}$. A final melting curve guaranteed the authenticity of the target product.

\section{Cell culture study}

Hepatocytes were taken from six male Sprague-Dawley rats (6 weeks old, 150-180 g), which were obtained from Charles River and fed a stock diet (Altromin). Hepatocytes were prepared by the collagenase perfusion technique (Seglen, 1976). The viability of the isolated cells, checked by trypan blue exclusion assay, was more than $90 \%$.

Cells were seeded into collagen-coated 24-well cell culture plates (Greiner Bio-one, Frickenhausen, Germany) to a density of $0.5 \times 10^{6}$ cells per well and millilitre in RPMI 1640 medium (with a basal concentration of $100 \mu \mathrm{M}$-methionine) supplemented with $10 \%$ fetal bovine serum, $50 \mathrm{mg} / \mathrm{l}$ gentamicin (all from Invitrogen) and insulin $(0.6 \mathrm{mg} / \mathrm{l})$ from porcine pancreas (Sigma-Aldrich). Cells were cultivated at $37^{\circ} \mathrm{C}$ in a humidified atmosphere of $95 \%$ air and $5 \% \quad \mathrm{CO}_{2}$. After $2-4 \mathrm{~h}$, the medium was removed and replaced by $400 \mu \mathrm{l}$ methionine-free RPMI 1640 medium (Biochrom AG, Berlin, Germany) supplemented with 50,100 or $200 \mu \mathrm{mol} / 1$ methionine, $10 \%$ fetal bovine serum, $50 \mathrm{mg} / \mathrm{l}$ gentamicin and $0.6 \mathrm{mg} / \mathrm{l}$ insulin. The final methionine concentrations in the media that resulted from supplementation with methionine and fetal bovine serum were 53, 103 and $203 \mu \mathrm{mol} / \mathrm{l}$, respectively. The medium containing $53 \mu \mathrm{mol} / \mathrm{l}$ methionine was used as control and corresponded to the plasma concentrations of methionine that were measured in the rat groups fed the low-methionine diets. After a further $24 \mathrm{~h}$, the cells were used to measure the phospholipid composition of the cells, the LDL uptake, the rate of cholesterol synthesis and the concentrations of homocysteine and methionine in the medium.

\section{Measurement of LDL uptake}

LDL $(1.006<\rho<1.063 ; \mathrm{kg} / \mathrm{l})$ was isolated by ultracentrifugation of EDTA plasma from normal lipidaemic human donors and labelled with the fluorochrome $1,1^{\prime}$-dioctadecyl-3,3,3',3'-tetramethylindocarbocyanine perchlorate (DiI) according to Zouhair \& Gurachek (1993) with modifications: $0.6 \mathrm{ml}$ LDL dialysed against PBS containing $0.1 \mathrm{mg} / \mathrm{ml}$ EDTA (mean protein concentration $800 \mu \mathrm{g} / \mathrm{ml}$ ) was mixed with a $100 \mathrm{mmol} / \mathrm{l}$ solution of ascorbic acid $(1 \mu \mathrm{l})$ to prevent oxidation and $2 \mu \mathrm{l}$ DiI in dimethyl sulphoxide $(33.6 \mathrm{mg} / \mathrm{ml})$. The mixture was incubated for $6 \mathrm{~h}$ at $37^{\circ} \mathrm{C}$ in the dark, under $\mathrm{N}$ gas and with gentle agitation. The DiI-labelled LDL was reisolated after sterile filtration $(0.2 \mu \mathrm{m})$ and density adjustment as an upper layer by ultracentrifugation and dialysed against PBS under $\mathrm{N}$ for $12 \mathrm{~h}$.

For uptake studies, cells were washed with RPMI 1640 medium without supplements and incubated with $200 \mu \mathrm{l}$ RPMI 1640 containing $10 \mu \mathrm{g}$ DiI-LDL protein for $2 \mathrm{~h}$ at $37^{\circ} \mathrm{C}$. After incubation, cells were washed twice with cold PBS, and lipids were extracted with $300 \mu$ isopropanol. The extracts were centrifuged at $10000 \mathrm{~g}$ for $5 \mathrm{~min}$, and the fluorescence was measured in the supernatant with the fluorescence detector of the 1100-HPLC (Agilent Technologies; excitation wavelength $520 \mathrm{~nm}$, emission wavelength $580 \mathrm{~nm}$ ). All incubations were replicated four times per animal. To determine 
the unspecific binding, cells were incubated with LDL in the presence of heparin $(80000 \mathrm{U} / \mathrm{l})$, which inhibits the LDL receptor-mediated uptake of LDL (Goldstein et al. 1976). The specific uptake was calculated by subtracting the unspecific binding from the total uptake.

Cellular protein concentration was measured after isopropanol extraction by solubilising the protein in $0.2 \mathrm{~mol} / \mathrm{l} \mathrm{NaOH}$ followed by the bicinchoninic acid assay. Uptake was expressed as ng LDL-protein per mg cell protein per $2 \mathrm{~h}$.

\section{Analysis of in vitro cholesterol synthesis}

Newly synthesised cholesterol was measured by the addition of $0.05 \mu \mathrm{Ci}\left[1,2-{ }^{14} \mathrm{C}\right]$ acetate (specific activity $108 \mathrm{mCi} /$ mmol; Hartmann Analytic, Braunschweig, Germany) to the culture media according to Mehran et al. (1995) and Lovati et al. (2000). Cells were incubated for $4 \mathrm{~h}$ at $37^{\circ} \mathrm{C}$. All incubations were replicated six times per animal. After incubation, the cells were washed twice with cold PBS and the culture plates stored at $-20^{\circ} \mathrm{C}$ pending analysis.

The lipids were extracted twice with a mixture of hexane and isopropanol (3:2, v/v; Liscum \& Faust, 1987). After removing the solvents in a vacuum centrifugal evaporator (Jouaie, SaintHerblain, France) the lipids were dissolved in $50 \mu \mathrm{l}$ chloroform, $3 \mu \mathrm{l}$ of which were applied to $10 \times 20 \mathrm{~cm}^{2}$ TLC sheets ( $\mathrm{Si} 60$ aluminium sheets, Cat.-No. 1.05 553.0001; VWR International) using a TLC spotter PS01 (Desaga, Heidelberg, Germany). Plates were developed with a mixture of hexane, diethyl ether and acetic acid (80:20:3, v/v/v; Levy et al. 1992). Lipid-bound radioactivity was detected and quantified by autoradiography (Fuji imager system, Tina 2 software; Raytest, Straubenhart, Germany) in relation to $\left[4-{ }^{14} \mathrm{C}\right]$ cholesterol standards (Biotrend Chemikalien $\mathrm{GmbH}$, Cologne, Germany). Cellular protein content was measured after the lipid extraction by solubilisation of protein in $0.2 \mathrm{~mol} / \mathrm{l} \mathrm{NaOH}$ solution using the bicinchoninic acid assay.

\section{Statistical analysis}

Data were analysed by ANOVA using Minitab Statistical Software (Minitab, State College, PA, USA). Differences between means were tested using Fisher's multiple range test when the $F$ value was significant at $P<0 \cdot 05$. Data were considered significantly different at $P<0 \cdot 05$. A linear regression analysis was performed between plasma homocysteine and plasma cholesterol concentrations.

\section{Results \\ Food intake and growth development of the rats}

Mean food intake (group 1: 19.7 (SEM 0.5) g/d; group 2: 19.1 (SEM 0.4) g/d; group 3: 18.6 (SEM 0.5) g/d; group 4: 18.9 (SEM $0 \cdot 6) \mathrm{g} / \mathrm{d} ; n$ 10) and body weight gain (group 1: 120 (SEM 4) g; group 2: 120 (SEM 3) g; group 3: 115 (SEM 5) g; group 4: 122 (SEM 4) g; $n$ 10) did not differ between the four groups of rats.

\section{Concentrations of amino acids in rat plasma and liver}

The methionine concentration in the plasma increased as the dietary methionine concentration rose (Table 2). The homocysteine concentrations in the plasma of rats fed 4.5 or $6.0 \mathrm{~g} / \mathrm{kg}$ methionine tended to be higher $(P=0.058)$ than the homocysteine concentrations in the plasma of rats fed 2.6 or $3.5 \mathrm{~g} / \mathrm{kg}$ methionine (Table 2). Rats fed a diet with $3.5 \mathrm{~g} / \mathrm{kg}$ methionine or more had lower concentrations of lysine $(P<0.05)$ and higher concentrations of histidine $(P<0.05)$ in their plasma than rats fed the diet with $2.6 \mathrm{~g} / \mathrm{kg}$ methionine (lysine, group 1: 725 (SEM 67) $\mu \mathrm{mol} / 1$; group 2: 489 (SEM 15) $\mu \mathrm{mol} / \mathrm{l}$; group 3: 563 (SEM 27) $\mu \mathrm{mol} / 1$; group $4: 545$ (SEM 30) $\mu \mathrm{mol} / \mathrm{l}$; histidine, group 1: 97.2 (SEM 6.8) $\mu \mathrm{mol} / \mathrm{l}$; group 2: 75.2 (SEM 4.1) $\mu \mathrm{mol} / 1$; group 3: 79.0 (SEM 5.0) $\mu \mathrm{mol} / \mathrm{l}$; group 4: 78.0 (SEM 3.3) $\mu \mathrm{mol} / \mathrm{l} ; n$ 10). The plasma concentrations of serine, taurine, cystine, ethanolamine, phenylalanine, tryptophan, leucine, isoleucine, valine, tyrosine, alanine, threonine, arginine, glutamine, glycine, glutamic acid and asparagine were no different between the four groups of rats (data not shown). Concentrations of homocysteine and SAM in the liver did not differ between the four groups of rats (Table 2). Rats fed the high-methionine diet with $6 \cdot 0 \mathrm{~g} / \mathrm{kg}$ methionine had higher concentrations of SAH in their livers than groups fed 2.6 or $3.5 \mathrm{~g} / \mathrm{kg}$ dietary methionine (Table 2). The ratio of SAH to SAM in liver did not differ between the four groups of rats (Table 2).

Table 2. Concentrations of methionine and homocysteine in plasma and concentrations of homocysteine, SAM and $\mathrm{SAH}$ in liver of growing rats fed diets with different concentrations of methionine

(Mean values with their standard errors for ten rats per group)

\begin{tabular}{|c|c|c|c|c|c|c|c|c|}
\hline \multirow[b]{2}{*}{ Dietary methionine (g/kg) } & \multicolumn{2}{|c|}{$2 \cdot 6$} & \multicolumn{2}{|c|}{3.5} & \multicolumn{2}{|c|}{4.5} & \multicolumn{2}{|c|}{$6 \cdot 0$} \\
\hline & Mean & SEM & Mean & SEM & Mean & SEM & Mean & SE \\
\hline \multicolumn{9}{|l|}{ Plasma } \\
\hline Methionine $(\mu \mathrm{mol} / \mathrm{l})$ & $50 \cdot 1$ & $3.2^{b}$ & $54 \cdot 3$ & $4 \cdot 0^{b}$ & $76 \cdot 1$ & $7 \cdot 1^{\mathrm{a}}$ & 81.9 & $8 \cdot 5^{\mathrm{a}}$ \\
\hline Homocysteine $(\mu \mathrm{mol} / \mathrm{l})$ & $5 \cdot 98$ & .47 & $6 \cdot 02$ & 0.51 & 8.03 & 0.62 & $8 \cdot 62$ & $1 \cdot 37$ \\
\hline \multicolumn{9}{|l|}{ Liver } \\
\hline Homocysteine $(\mathrm{nmol} / \mathrm{g})$ & $5 \cdot 0$ & 0.5 & $4 \cdot 3$ & 0.4 & $5 \cdot 3$ & 0.6 & 4.4 & 0.4 \\
\hline SAM (nmol/g) & 123 & 12 & 125 & 9 & 142 & 9 & 150 & 9 \\
\hline $\mathrm{SAH}(\mathrm{nmol} / \mathrm{g})$ & $24 \cdot 2$ & $1 \cdot 6^{\mathrm{b}}$ & $24 \cdot 2$ & $2 \cdot 2^{b}$ & $28 \cdot 8$ & $2 \cdot 4^{\mathrm{a}, \mathrm{b}}$ & $32 \cdot 6$ & $1 \cdot 7^{\mathrm{a}}$ \\
\hline $\mathrm{SAH}: \mathrm{SAM}$ ratio $(\mathrm{nmol} / \mathrm{nmol})$ & $0 \cdot 21$ & 0.02 & 0.20 & 0.02 & 0.21 & 0.02 & 0.22 & 0.02 \\
\hline
\end{tabular}

SAM, S-adenosylmethionine; SAH, S-adenosylhomocysteine.

${ }_{\mathrm{a}, \mathrm{b}}$ Mean values within a row with unlike superscript letters were significantly different $(P<0.05)$

For details of diets and procedures, see p. 880. 
Lipid concentrations in plasma, lipoproteins and liver of rats

Concentrations of cholesterol in the plasma, liver and lipoprotein fractions with densities $(\mathrm{kg} / \mathrm{l})$ of $1.006<\rho<1.063$ and $\rho>1.063$ were higher in rats fed the diets with $3.5 \mathrm{~g} / \mathrm{kg}$ methionine or more than in rats fed the low-methionine diet containing $2.6 \mathrm{~g} / \mathrm{kg}$ methionine (Table 3). The concentration of cholesterol in the lipoprotein fraction with a density $(\mathrm{kg} / \mathrm{l})$ of $\rho<1.006$ was not significantly different between the groups. The phosphatidylcholine:phosphatidylethanolamine ratio in the liver increased as the dietary methionine concentration rose (Table 3). The ratio of $20: 4 n-6: 18: 2 n-6$ fatty acid in phosphatidylcholine was higher in the rats fed diets containing 4.5 or $6.0 \mathrm{~g} / \mathrm{kg}$ methionine than in rats fed diets containing $2.6 \mathrm{~g} / \mathrm{kg}$ methionine (Table 3 ). The ratio of 20 : $4 n-6: 18: 2 n-6$ in phosphatidylethanolamine did not differ between the four groups of rats.

\section{Correlation between plasma homocysteine and plasma cholesterol concentrations}

Regression analysis showed a weak positive correlation between the concentrations of plasma homocysteine and plasma cholesterol $(P<0 \cdot 01$; Fig. 1$)$.

\section{Faecal excretion of bile acids}

The excretion of bile acids via the faeces was no different between the four groups of rats (group 1: 83.1 (SEM 7.4) $\mu \mathrm{mol} /$ week; group 2: 80.2 (SEM 7.0) $\mu \mathrm{mol} /$ week; group 3: $69 \cdot 7$ (SEM 4.8) $\mu \mathrm{mol} /$ week; group 4: $86 \cdot 3$ (SEM 7·1) $\mu \mathrm{mol} /$ week; $n$ 10).

\section{Gene expression of hepatic enzymes and $L D L$ receptor in rats}

The relative mRNA concentration of HMG-CoA reductase in the liver increased with rising dietary methionine concentration (Fig. 2(a)). The relative gene expression of PEMT in the liver did not differ between the four groups of rats (group 1: 0.91 (SEM 0.26); group 2: 1.24 (SEM 0.29); group 3: 1.00 (SEM 0.21); group 4: 0.70 (SEM 0.11); $n$ 10).

The relative mRNA concentration of CYP7A1 in the liver was higher in rats fed diets with $6.0 \mathrm{~g} / \mathrm{kg}$ methionine than in rats fed diets with 2.6 or $3.5 \mathrm{~g} / \mathrm{kg}$ methionine (Fig. 2(b)). Rats fed the diet with $4.5 \mathrm{~g} / \mathrm{kg}$ methionine did not differ from rats fed the diet with $2.6,3.5$ or $6.0 \mathrm{~g} / \mathrm{kg}$ methionine diet in terms of their relative mRNA concentration of CYP7A1 (Fig. 2(b)).

Relative gene expressions of cystathione $\beta$-synthase (group 1: 0.93 (SEM 0.10); group 2: 1.28 (SEM 0.26); group 3: 1.00 (SEM $0.21)$; group 4: 1.05 (SEM 0.21); $n 10), \Delta 6$-desaturase (group 1: 1.24 (SEM 0.30); group 2: 1.13 (SEM 0.18); group 3: 1.00 (SEM $0 \cdot 17)$; group 4: $1.84(\operatorname{SEM} 0 \cdot 41) ; n 10)$ and the LDL receptor (group 1: 1.00 (SEM 0.30); group 2: 1.28 (SEM 0.46); group 3: $1 \cdot 00$ (SEM 0.32); group 4: 1.21 (SEM 0.46); $n$ 10) in the liver did not differ between the four groups of rats.

\section{Phosphatidylcholine:phosphatidylethanolamine ratio, cholesterol synthesis and LDL uptake in rat hepatocytes}

The phosphatidylcholine:phosphatidylethanolamine ratio and LDL uptake did not differ between cells incubated in media supplemented with 50 (control medium), 100 or $200 \mu \mathrm{mol} / \mathrm{l}$ methionine (Table 4). However, cells incubated in media supplemented with 100 or $200 \mu \mathrm{mol} / \mathrm{l}$ methionine had a higher rate of cholesterol synthesis than cells incubated in the control medium supplemented with $50 \mu \mathrm{mol} / \mathrm{l}$ methionine. After incubating the cells for $24 \mathrm{~h}$, the concentrations of homocysteine in the cell culture media increased significantly with increasing amounts of supplemented methionine (Table 4).

\section{Discussion}

The present study shows that methionine added to a diet containing the minimum level of methionine required for rat

Table 3. Concentration of cholesterol in the plasma, lipoprotein fractions and liver, phosphatidylcholine:phosphatidylethanolamine ratio in the liver and ratio of $20: 4 n-6: 18: 2 n-6$ in the liver phospholipids of growing rats fed diets with different concentrations of methionine

(Mean values with their standard errors for ten rats per group)

\begin{tabular}{|c|c|c|c|c|c|c|c|c|}
\hline \multirow[b]{2}{*}{ Dietary methionine (g/kg) } & \multicolumn{2}{|c|}{$2 \cdot 6$} & \multicolumn{2}{|c|}{$3 \cdot 5$} & \multicolumn{2}{|c|}{4.5} & \multicolumn{2}{|c|}{$6 \cdot 0$} \\
\hline & Mean & SEM & Mean & SEM & Mean & SEM & Mean & SEM \\
\hline Plasma (mmol/l) & $2 \cdot 13$ & $0.11^{b}$ & $2 \cdot 51$ & $0.09^{a}$ & $2 \cdot 72$ & $0.11^{a}$ & 2.53 & $0.11^{a}$ \\
\hline \multicolumn{9}{|l|}{ Lipoprotein fractions (mmol/l) } \\
\hline$\rho<1.006$ & 0.32 & 0.05 & 0.36 & 0.03 & 0.40 & 0.04 & $0 \cdot 38$ & 0.02 \\
\hline $1.006<\rho<1.063$ & 0.61 & $0.05^{\mathrm{b}}$ & 0.76 & $0.05^{a}$ & 0.82 & $0.05^{\mathrm{a}}$ & 0.76 & $0.04^{a}$ \\
\hline$\rho>1.063$ & $1 \cdot 17$ & $0.06^{\mathrm{b}}$ & $1 \cdot 36$ & $0.07^{a, b}$ & 1.47 & $0.07^{\mathrm{a}}$ & 1.49 & $0 \cdot 11^{\mathrm{a}}$ \\
\hline Liver $(\mu \mathrm{mol} / \mathrm{g})$ & $5 \cdot 62$ & $0.61^{\mathrm{a}}$ & $8 \cdot 64$ & $1 \cdot 37^{\mathrm{a}, \mathrm{b}}$ & $9 \cdot 92$ & $1 \cdot 32^{b}$ & $9 \cdot 41$ & $1 \cdot 42^{\mathrm{b}}$ \\
\hline \multicolumn{9}{|l|}{ Phospholipids } \\
\hline $\begin{array}{l}\text { Liver phosphatidylcholine: phosphatidylethanolamine } \\
\text { ratio }(\mathrm{mol} / \mathrm{mol})\end{array}$ & $2 \cdot 62$ & $0.04^{b}$ & $2 \cdot 91$ & $0 \cdot 23^{a, b}$ & 3.50 & $0 \cdot 31^{a, b}$ & 3.75 & $0.37^{\mathrm{a}}$ \\
\hline \multicolumn{9}{|l|}{ Fatty acids } \\
\hline $\begin{array}{l}\text { Liver phosphatidylcholine: } 20: 4 n-6: 18: 2 n-6 \\
\quad \text { ratio }(\mathrm{mol} / \mathrm{mol})\end{array}$ & 3.08 & $0.26^{b}$ & 3.97 & $0.73^{\mathrm{a}, \mathrm{b}}$ & $4 \cdot 35$ & $0 \cdot 17^{\mathrm{a}}$ & 4.53 & $0 \cdot 20^{\mathrm{a}}$ \\
\hline $\begin{array}{l}\text { Liver phosphatidylethanolamine: } 20: 4 n-6: 18: 2 n-6 \\
\text { ratio }(\mathrm{mol} / \mathrm{mol})\end{array}$ & $2 \cdot 72$ & 0.07 & 3.09 & $0 \cdot 11$ & $2 \cdot 95$ & 0.07 & 3.03 & $0 \cdot 11$ \\
\hline
\end{tabular}

$\rho$, density $(\mathrm{kg} / \mathrm{l})$.

a,b Mean values within a row with unlike superscript letters were significantly different $(P<0.05)$.

For details of diets and procedures, see p. 880. 


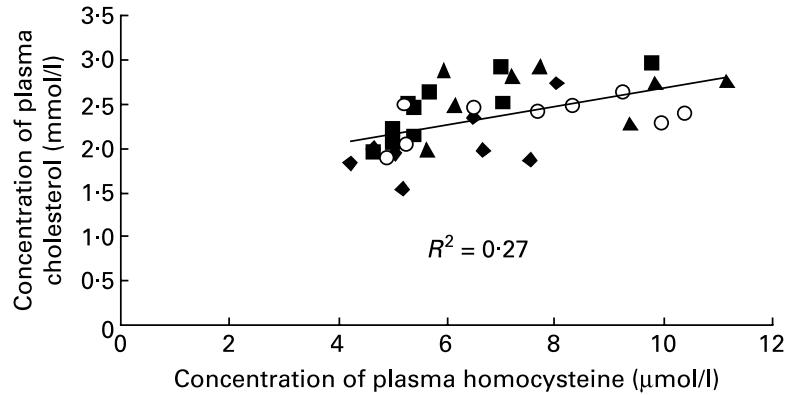

Fig. 1. Correlation between concentrations of plasma homocysteine and plasma cholesterol in growing rats fed diets that contained different amounts of methionine $(P<0.01)$. The coefficient of determination $\left(R^{2}\right)$ between plasma homocysteine and plasma cholesterol was 0.30 . The regression equation is $\mathrm{Y}=1.66+0.106 \mathrm{X}(\mathrm{Y}$, plasma cholesterol concentration, $\mathrm{mmol} / \mathrm{l}$;

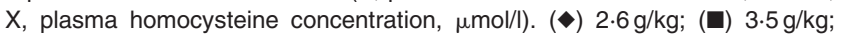
(४) $4.5 \mathrm{~g} / \mathrm{kg}$; (○) $6.0 \mathrm{~g} / \mathrm{kg}$.

growth increases cholesterol concentrations in the plasma and liver. This is in agreement with several reports showing that methionine supplementation of a low-methionine diet, for example a soyabean protein diet, causes hypercholesterolaemia in rats (Oda et al. 1989; Tanaka \& Sugano, 1989; Saeki et al. 1990; Sugiyama et al. 1996, 1997).
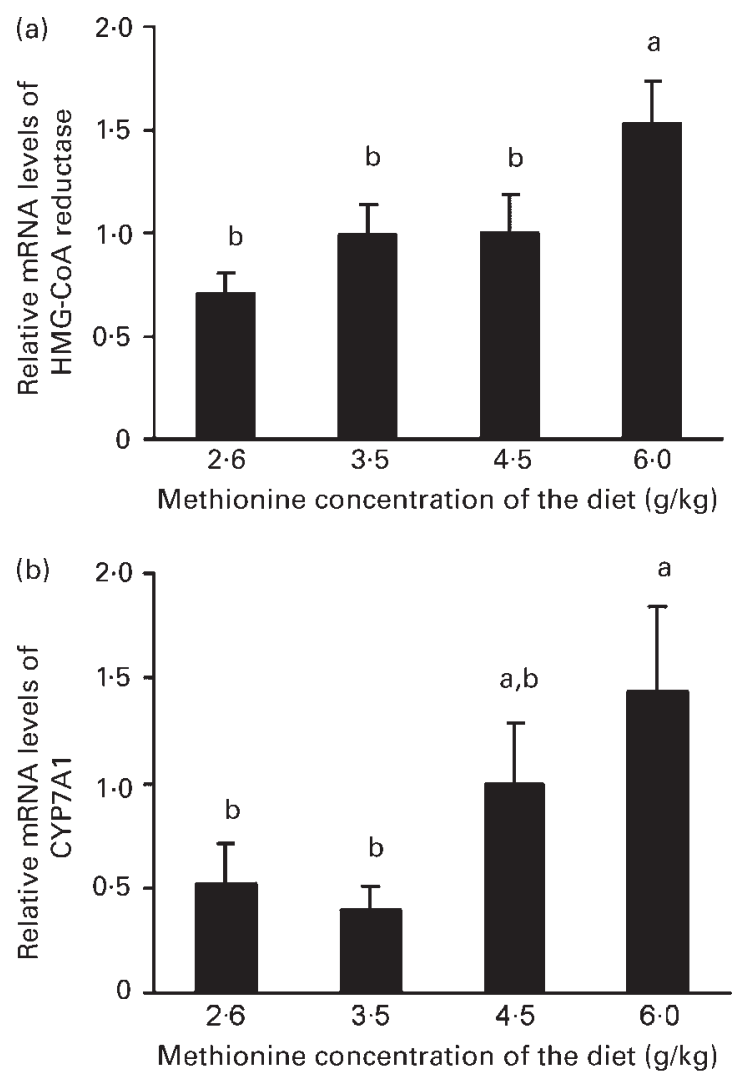

Fig. 2. (a) 3-Hydroxy-3-methylglutaryl coenzyme $A$ (HMG-CoA) reductase mRNA, and (b) cholesterol-7 $\alpha$-hydroxylase (CYP7A1) mRNA in the liver of growing rats fed $2.6,3.5,4.5$ or $6.0 \mathrm{~g}$ methionine per $\mathrm{kg}$ diet for $14 \mathrm{~d}$. Bars represent the means with their standard errors for ten rats. The mRNA concentrations of the rats fed $4.5 \mathrm{~g} / \mathrm{kg}$ methionine were defined as 1 , and the mRNA concentrations of the other groups were ascertained in relation to the mRNA concentrations of the group fed $4.5 \mathrm{~g} / \mathrm{kg}$ methionine. ${ }^{\mathrm{a}, \mathrm{b}, \mathrm{c}}$ Mean values with unlike superscript letters were significantly different $(P<0.05)$. For details of diets and procedures, see p. 880.
In the present study, we observed that a moderate excess of dietary methionine increased the gene expression of HMGCoA reductase in the liver of rats. Moreover, we observed that primary rat hepatocytes incubated with media supplemented with 100 or $200 \mu \mathrm{mol} / \mathrm{l}$ methionine had a higher cholesterol synthesis than cells incubated with a control medium that was supplemented with $50 \mu \mathrm{mol} / \mathrm{l}$ methionine. These observations suggest that methionine is able to stimulate cholesterol synthesis in liver cells. For technical reasons, we did not measure in vivo cholesterol synthesis in the rats. Nevertheless, the finding of elevated HMG-CoA reductase MRN levels in rat liver and of increased in vitro cholesterol synthesis in rat hepatocytes suggests that dietary methionine could have a hypercholesterolaemic action that is at least in part due to increased hepatic cholesterol synthesis.

The rat study was performed without any supplementation of exogenous cholesterol. Cholesterol is known to be an effective feedback inhibitor of HMG-CoA reductase, the key enzyme in endogenous cholesterol synthesis (Ott \& Lachance, 1981). The observed effect of a moderate methionine excess on the expression of HMG-CoA reductase is therefore representative only for the experimental conditions used, but would possibly be modified by different dietary conditions, such as dietary cholesterol. The observed stimulation of HMG-CoA reductase expression in the high-methionine group is in agreement with observations by Woo et al. (2005), who showed that the mRNA concentration and activity of HMG-CoA reductase were significantly increased in the livers of rats fed a high-methionine diet with $17 \mathrm{~g} / \mathrm{kg}$ methionine. In that study, homocysteine was suggested to be a stimulator of cholesterol synthesis in the liver via activation of the transcription factor SREBP-2 (Woo et al. 2005). We observed that the concentration of homocysteine in the media of primary rat hepatocytes markedly increased with increasing amounts of methionine added to the media. It therefore seems possible that homocysteine could have stimulated cholesterol synthesis in primary hepatocytes. However, the fact that there was only a weak positive correlation between the plasma concentrations of homocysteine and cholesterol in the rats fed diets with different methionine concentrations, together with the observation that plasma homocysteine concentrations were not significantly different between the rats fed diets with methionine concentrations between 2.6 and $6 \cdot 0 \mathrm{~g} / \mathrm{kg}$, did not fully support this hypothesis. Thus, it is doubtful whether homocysteine by itself was responsible for the observed alterations in cholesterol metabolism.

However, an increase in plasma and liver cholesterol concentration was not only observed in the group fed $6.0 \mathrm{~g} / \mathrm{kg}$ methionine but also in the groups fed 3.5 and $4.5 \mathrm{~g} / \mathrm{kg}$ methionine compared with the group fed the low-methionine diet, although the relative mRNA concentrations of HMG-CoA reductase were not increased in these groups. It is fairly likely, therefore, that methionine influenced plasma and liver cholesterol concentrations not only by increasing the rate of cholesterol synthesis, but also by other mechanisms. Moreover, differences in the LDL receptor pathways do not seem to be responsible for the hypercholesterolaemic effect of dietary methionine because neither LDL receptor expression in the rats nor the uptake of LDL into cultivated hepatocytes was affected by methionine supplementation. We therefore cannot confirm the proposal that dietary methionine has a 
Table 4. Phosphatidylcholine:phosphatidylethanolamine (PC:PE) ratio, rate of cholesterol synthesis, LDL uptake in primary hepatocytes, and methionine and homocysteine concentrations in the medium after incubation in media supplemented with 50,100 or $200 \mu \mathrm{mol} / \mathrm{l}$ methionine for $24 \mathrm{~h}$

(Mean values with their standard errors*)

\begin{tabular}{|c|c|c|c|c|c|c|}
\hline \multirow[b]{2}{*}{ Methionine supplementation $(\mu \mathrm{mol} / \mathrm{l})$} & \multicolumn{2}{|c|}{50} & \multicolumn{2}{|c|}{100} & \multicolumn{2}{|c|}{200} \\
\hline & Mean & SEM & Mean & SEM & Mean & SEM \\
\hline PC:PE ratio (mol/mol) & $3 \cdot 14$ & 0.51 & $3 \cdot 14$ & 0.43 & 3.48 & 0.51 \\
\hline Cholesterol synthesis (dpm/ $\mu$ g cell protein per $4 \mathrm{~h})$ & $7 \cdot 3$ & $1.9^{b}$ & $12 \cdot 5$ & $2 \cdot 8^{\mathrm{a}}$ & $12 \cdot 8$ & $2 \cdot 4^{\mathrm{a}}$ \\
\hline LDL uptake (ng LDL-protein/mg cell protein per $2 \mathrm{~h}$ ) & 176 & 27 & 192 & 28 & 200 & 43 \\
\hline Methionine $(\mu \mathrm{mol} / \mathrm{l})$ & $45 \cdot 8$ & $3 \cdot 5^{\mathrm{c}}$ & 81.5 & $2 \cdot 0^{\mathrm{b}}$ & 138 & $21^{a}$ \\
\hline Homocysteine $(\mu \mathrm{mol} / \mathrm{l})$ & $11 \cdot 0$ & $3 \cdot 5^{c}$ & $16 \cdot 8$ & $1 \cdot 7^{\mathrm{b}}$ & $37 \cdot 2$ & $2 \cdot 4^{a}$ \\
\hline
\end{tabular}

*Six rats for PC:PE ratio and cholesterol synthesis; five rats for LDL uptake; three rats for methionine and homocysteine in medium.

$a, b, c$ Mean values within a row with unlike superscript letters were significantly different $(P<0.05)$.

For details of diets and procedures, see p. 880 .

hypercholesterolaemic action by downregulating LDL receptors (Sugiyama et al. 1998).

The increased plasma cholesterol concentration in rats fed methionine-supplemented diets in the present study was mainly caused by an increase in circulating lipoprotein fractions with densities of over $1.063 \mathrm{~kg} / \mathrm{l}$ and densities between 1.006 and $1.063 \mathrm{~kg} / \mathrm{l}$. The cut-off point chosen for lipoprotein separation was typical for human subjects but matched that used in previous rat studies (Geelen \& Beynen, 2000; Giudetti et al. 2003). This means that the rat lipoprotein fraction with a density of $\rho>1.063 \mathrm{~kg} / \mathrm{l}$ contained only HDL, whereas the $1.006<\rho<1.063$ lipoprotein fraction also included intermediate-density lipoproteins, LDL and some HDL particles. Adding methionine to a low-methionine diet therefore mainly increased HDL, which normally promotes the transfer of peripheral free cholesterol to the liver by a mechanism known as 'reverse cholesterol transfer'. A methionine-induced increase in LDL and intermediate-density lipoprotein concentration could not, however, be ruled out. The mechanism responsible for the strong effect of methionine on HDL-cholesterol is not yet clear from the data analysed.

It is known that an increase in homocysteine concentration raises the level of homocysteine thiolactone, which can react with proteins by a mechanism involving the homocysteinylation of protein lysine residues, a process that damages proteins (Jakubowski, 2000a). Paraoxogenase is an enzyme that protects proteins against homocysteinylation by detoxifying homocysteine thiolactone (Jakubowski, 2000b) and is associated with the HDL fraction of serum lipoproteins (Jakubowski, 2000a). A recent study has shown that paraoxogenase activity, which is responsible for the detoxification of homocysteine thiolactone, correlates positively with the concentration of HDL cholesterol (Rozek et al. 2005). It would appear, therefore, that a link between the HDL-cholesterol concentration and the homocysteine concentration in this study is conceivable.

Another factor involved in cholesterol homeostasis is the excretion of cholesterol via bile acids. The conversion of cholesterol to $7 \alpha$-hydroxylated bile acids is the principal pathway of cholesterol disposal. CYP7A1 is the initial and rate-limiting enzyme in the 'classic' pathway of bile acid synthesis, the major pathway for the elimination of cholesterol from the body. However, the concentrations of the relative mRNA of CYP7A1 were not indicative of diminished cholesterol excretion in the methionine-supplemented rats because the livers of rats fed the high-methionine diet showed a higher CYP7A1 expression rate than the livers of rats fed less methionine. In addition, the excretion of bile acids was no different between the groups fed low or high amounts of dietary methionine.

On the other hand, alterations in the methionine/homocysteine pathway are also believed to have a hypercholesterolaemic action by increasing the phosphatidylcholine:phosphatidylethanolamine ratio in the liver, which in turn raises the concentration of cholesterol in the plasma (Sugiyama et al. 1996, 1998; Giroux et al. 1999). The present finding of an increased hepatic phosphatidylcholine:phosphatidylethanolamine ratio in rats fed high-methionine diets confirms these results. However, the observation that hepatic PEMT gene expression was independent of the dietary methionine concentration suggests that the methionine-induced methylation of phosphatidylethanolamine was not regulated by the mRNA concentration of that enzyme. However, the fact that there was an in vitro stimulation of cholesterol synthesis when adding 100 instead of $50 \mu \mathrm{mol} / \mathrm{l}$ methionine to the cell culture media without any alteration in the phosphatidylcholine:phosphatidylethanolamine ratio suggests that the methionine-induced cholesterol synthesis was not primarily caused by altered phosphatidylcholine formation.

Another observation was that rats fed diets with a high methionine level exhibited an increased ratio of 20 : $4 n-6: 18: 2 n-6$ in liver phosphatidylcholine. This suggests an increased activity of $\Delta 6$-desaturase, although the gene expression of that enzyme was not altered by dietary methionine. The activity of $\Delta 6$-deasturase, an integral protein of microsomal membranes, is strictly controlled by membrane fluidity (Brenner, 1981). Enrichment of the microsomal membranes with cholesterol lowers their fluidity and increases the activity of $\Delta 6$-desaturase (Garda \& Brenner, 1985). Although we did not measure cholesterol in the microsomal membranes, we suspect that increased $\Delta 6$-desaturation in rats fed highmethionine diets may have been the result of the increased hepatic cholesterol concentrations observed in these animals.

In conclusion, this rat experiment confirms others that have shown that methionine supplementation of a low-methionine diet increases plasma cholesterol concentration in rats. The present study suggests that a moderate excess of dietary methionine may, at least in part, increase the concentration of plasma and liver cholesterol by stimulating cholesterol synthesis. 


\section{Acknowledgements}

This work was supported by a grant from the Deutsche Forschungsgemeinschaft (DFG).

\section{References}

Bassler R \& Buchholz H (1993) Methodenbuch Band III. Die chemische Untersuchung von Futtermitteln, 3, Darmstadt, Germany: Ergänzungslieferung. VDLUFA-Verlag.

Brenner RR (1981) Nutritional and hormonal factors influencing desaturation of essential fatty acids. Progr Lipid Res 20, 41-47.

Butte W (1983) Rapid method for the determination of fatty acid profiles from fats and oils using trimethylsulfonium hydroxide for transesterification. J Chromatogr 261, 142-145.

Carroll KK \& Kurowska EM (1995) Soy consumption and cholesterol reduction: review of animal and human studies. J Nutr 125, 594S-597S.

Christie WW (1985) Chromatographic analysis of phospholipids. Z Lebensm Unters Forsch 181, 171-182.

De Hoff JL, Davidson JH \& Kritchevsky V (1978) An enzymatic assay for determining free and total cholesterol in tissues. Clin Chem 24, 433-435.

Dongowski G, Huth M, Gebhardt E \& Flamme W (2002) Dietary fiber-rich barley products beneficially affect the intestinal tract of rats. J Nutr 132, 3704-3714.

Eder K \& Brandsch C (2002) Effect of fatty acid composition of rapeseed oil on plasma lipids, fatty acid composition of tissues and susceptibility of low-density lipoprotein to lipid peroxidation in cholesterol-fed hamsters. Eur J Lipid Sci Technol 104, 3-13.

Garda HA \& Brenner RR (1985) In vitro modification of cholesterol content of rat liver microsomes. Effects upon membrane fluidity and activities of glucose-6-phosphatase and fatty acid desaturation synthesis. Biochim Biophys Acta 819, 45-54.

Geelen MJH \& Beynen AC (2000) Consumption of olive oil has opposite effects on plasma total cholesterol and sphingomyelin concentrations in rats. Br J Nutr 83, 541-547.

Giroux I, Kurowska EM, Freeman DJ \& Carroll KK (1999) Addition of arginine but not glycine to lysine plus methionine-enriched diets modulates serum cholesterol and liver phospholipid in rabbits. J Nutr 129, 1807-1813.

Giudetti AM, Beynen AC, Lemmens AG, Gnoni GV \& Geelen MJH (2003) Hepatic fatty acid metabolism in rats fed diets with different contents of $\mathrm{C}_{18: 0}, \mathrm{C}_{18: 1}$ cis and $\mathrm{C}_{18: 1}$ trans isomers. Br J Nutr 90, 887-893

Goldstein JL, Basu SK \& Brunsched GY (1976) Release of low density lipoprotein from its cell surface receptor by sulfated glycosaminoglycans. Cell 7, 85-95.

Hara A \& Radin NS (1978) Lipid extraction of tissues with a low toxicity solvent. Anal Biochem 90, 420-426.

Ikeda A, Imaizumi K \& Sugano M (1993) Interaction of dietary protein and fat on plasma cholesterol and amino acid levels, fatty acid desaturation, and prostacyclin production in exogenous hypercholesterolemic rats. Biosci Biotechnol Biochem 57, $1867-1872$.

Jakubowski H (2000a) Homocysteine thiolactone: metabolic origin and protein homocysteinylation in humans. J Nutr 130, 377S-381S

Jakubowski H (2000b) Calcium-dependent human serum homocysteine thiolactone hydrolase: a protective mechanism against protein N-homocysteinylation. J Biol Chem 275, 3957-3962.

Kritchevsky D (1993) Dietary protein and experimental atherosclerosis. Ann NY Acad Sci 676, 180-187.

Levy E, Thibault L \& Menard D (1992) Intestinal lipids and lipoproteins in the human fetus: modulation by epidermal growth factor. J Lipid Res 33, 1607-1617.
Liscum L \& Faust JR (1987) Low density lipoprotein (LDL)mediated suppression of cholesterol synthesis and LDL uptake is defective in Niemann-Pick type C fibroblasts. J Biol Chem 262, $17002-17008$

Lovati MR, Manzoni C, Gianazza E, Arnoldi A, Kurowska E, Carroll K \& Sirtori CR (2000) Soy protein peptides regulate cholesterol homeostasis in HepG2 cells. J Nutr 130, 2543-2549.

Marlett JA \& Fischer MH (2002) A poorly fermented gel from psyllium seed husk increases excreta moisture and bile acid excretion in rats. $J$ Nutr 132, 2638-2643.

Mehran M, Seidman E, Marchand R, Gurbindo C \& Levy E (1995) Tumor necrosis factor-alpha inhibits lipid and lipoprotein transport by Caco-2 cells. Am J Physiol 269, G953-G960.

National Research Council (1995) Nutrient Requirements of Laboratory Animals. Washington, DC: National Academy of Sciences.

Oda H, Okumura Y, Hitomi Y, Ozaki K, Nagaoka S \& Yoshida A (1989) Effect of dietary methionine and polychlorinated biphenyls on cholesterol metabolism in rats fed a diet containing soy protein isolate. J Nutr Sci Vitaminol 35, 333-348.

Ott DB \& Lachance PA (1981) Biochemical controls of liver cholesterol biosynthesis. Am J Clin Nutr 34, 2295-2306.

Reeves PG, Nielsen FH \& Fahey GC (1993) AIN-93 purified diets for laboratory rodents: final report of the American Institute of Nutrition Ad Hoc Writing Committee on the reformulation of the AIN-76A rodent diet. $J$ Nutr 123, 1939-1951.

Rozek LS, Hatsukami TS, Richter RJ, et al. (2005) The correlation of paraoxonase (PON1) activity with lipid and lipoprotein levels differs with vascular disease status. J Lipid Res 46, $1888-1895$.

Saeki S, Kanauchi O \& Kiriyama S (1990) Some metabolic aspects of the hypocholesterolemic effect of soybean protein in rats fed a cholesterol-free diet. J Nutr Sci Vitaminol 36, 125S-131S.

Schuster R (1988) Determination of amino acids in biological, pharmaceutical, plant and food samples by automated precolumn derivatization and high-performance liquid chromatography. J Chromatogr 431, 271-284.

Seglen PO (1976) Preparation of isolated rat liver cells. Methods Cell Biol 13, 29-83.

Sehayek E, Wang R, Ono JG, Zinchuk VS, Duncan EM, Shefer S, Vance DE, Ananthanarayanan M, Chait BT \& Breslow JL (2003) Localization of the PE methylation pathway and SR-BI to the canalicular membrane: evidence for apical phosphatidylcholine biosynthesis that may promote biliary excretion of phospholipid and cholesterol. J Lipid Res 44, 1605-1613.

Shimano H, Yahagik H, Amemiya-Kudo M, et al. (1999) Sterol regulatory element-binding protein-1 as a key transcription factor for nutritional induction of lipogenic enzyme genes. $J$ Biol Chem 274, 35832-35839.

Sirtori CR, Even R \& Lovati MR (1993) Soybean protein diet and plasma cholesterol: from therapy to molecular mechanism. Ann NY Acad Sci 676, 188-201.

Sugano M \& Koba K (1993) Dietary protein and lipid metabolism: a multifunctional effect. Ann NY Acad Sci 676, 215-222.

Sugiyama K, Akachi T \& Yamakawa A (1995) Eritadenine-induced alteration of hepatic phospholipids metabolism in relation to its hypocholesterolemic action in rats. $J$ Nutr Biochem 6, 80-87.

Sugiyama K, Kanamori H, Akachi T \& Yamakawa A (1996) Amino acid composition of dietary proteins affects plasma cholesterol concentration through alteration of hepatic phospholipid metabolism in rats fed a cholesterol-free diet. J Nutr Biochem 7, 40-48.

Sugiyama K, Kumazawa A, Zhou H \& Saeki S (1998) Dietary methionine level affects linoleic acid metabolism through phosphatidylethanolamine N-methylation in rats. Lipids 33, 235-242.

Sugiyama K, Yamakawa A, Kumazawa A \& Saeki S (1997) Methionine content of dietary proteins affects the molecular species 
composition of plasma phosphatidylcholine in rats fed a cholesterol-free diet. $J$ Nutr 127, 600-607.

Tanaka K \& Sugano M (1989) Effects of addition of sulfur-containing amino acids and glycine to soybean protein and casein on serum cholesterol levels in rats. J Nutr Sci Vitaminol 35, 323-332.

Teerlink T, van Leeuwen PA \& Hondijk A (1994) Plasma amino acids determined by liquid chromatography within 17 minutes. Clin Chem 40, 245-249.

Vester B \& Rasmussen K (1991) High performance liquid chromatography method for rapid and accurate determination of homocysteine in plasma and serum. Eur J Clin Biochem 29, 549-554.
Woo CWH, Siow YL, Pierce GN, Choy PC, Minuk GY, Mymin D \& Karmin O (2005) Hyperhomocysteinemia induces hepatic cholesterol biosynthesis and lipid accumulation via activation of transcription factors. Am J Physiol Endocrinol Metab 288, E1002-E1010.

Yao Z \& Vance DE (1988) The active synthesis of phosphatidylcholine is required for very low density lipoprotein secretion from rat hepatocytes. J Biol Chem 263, 2998-3004.

Zouhair FS \& Gurachek EC (1993) Rapid fluorimetric assay of LDL receptor activity by DiI-labeled LDL. J Lipid Res 34, $325-330$. 